\title{
Preliminary Screening for Anti-Inflammatory, Anti-Nociceptive and Antioxidant Activities of Five New Synthesized Paratoluene Sulphonamide Derivatives of Amino Acids
}

\author{
Ikpa C.B.C ${ }^{1, a}$, Okoro U.C. ${ }^{2, b}$, Ubochi $C^{1, c}$, Nwanorh K.O ${ }^{1, d}$, Onoja, S.O.,e* \\ ${ }^{1}$ Department of Chemistry, Imo State University Owerri, Nigeria \\ ${ }^{2}$ Department of Chemistry, University of Nigeria, Nsukka, Nigeria. \\ $3^{3}$ Department of Veterinary, Physiology, Pharmacology, Biochemistry and Animal Health and \\ Production, College of Veterinary Medicine, Micheal Okpara University of Agriculture, PMB 7267, \\ Umudike, Abia State, Nigeria +2348030613032 \\ aikpacbc@gmail.com, buchechukwuokoro639@gmail.com, cubochicollins@yahoo.com, \\ doharleykieran@yahoo.com, e*samonreal@yahoo.com, e*samuelonoja19@yahoo.com
}

Keywords: anti-inflammatory, antinociceptive, Paratoluene, Sulphonamide Derivatives, Amino Acids

\begin{abstract}
The anti-inflammatory, antinociceptive and antioxidant activities of five new synthesized paratoluene sulphonamide derivatives of amino acids were evaluated in this study. The antiinflammatory and antinociceptive was evaluated using egg albumin induced paw edema and tail flick rat model respectively, at the dose of $400 \mathrm{mg} / \mathrm{kg}$; while the antioxidant activity was evaluated in vitro using 2, 2-Diphenyl-1-Picrylhydrazyl (DPPH) scavenging and Ferric Reducing Antioxidant Power assay. The compounds produced various degrees of anti-inflammatory and antinociceptive activities but did not produce antioxidant effect. The sulphonamide derivative has antiinflammatory and antinociceptive properties and can be used as drug for this purpose.
\end{abstract}

\section{Introduction}

Inflammation is biological response of vascular tissues to injurious stimuli, such as pathogens, damaged cells, and irritant agents [1]. It is protective mechanisms by the organism remove the injurious stimuli as well as initiates the healing process for the tissue. Inflammation is the consequence of increased cell membrane permeability that may be initiated by changes in membrane lipids by reactive oxygen species. The increased capillary dilation causes redness and pain, and escape of plasma into the surrounding tissue giving rise to edema. Inflammation is modulated by cytokines. Reactive oxygen species associated with inflammatory responses are formed by the reduction of tissue oxygen, and include peroxide, superoxide anion, the hydroxyl radical, and singlet oxygen [2]. Inflammation is clinically managed with anti-inflammatory drugs; which are mostly cyclooxygenase (COX) inhibitor with known side effects of gastric ulcerations [3]. The interest now is on the synthesis of selective COX-2 inhibitors which are devoid of gastric ulceration. Celecoxib and rofecoxib are sulphonamide derivatives with selective COX-2 inhibitor activity [4].

The sulfonamides comprise important class of drugs, with many types of pharmacological properties such as antibacterial, diuretic, hypoglycemic, antithyroid, antiviral, anti-inflammatory and anticancer activities [5]. Several thousand derivatives of sulfonamides have been synthesized; studied and the best therapeutic results were obtained from the compounds in which one hydrogen atom of the $\mathrm{SO}_{2} \mathrm{NH}_{2}$ group was replaced with heterocyclic ring [6]. The aniline, amino group is very important for activity and modification of it may lead to loss of activity [7]. Also, sulfonamides are inactive when $p$-amino group is acylated, benzene is substituted, sulfonamide group not attached directly to benzene ring. This study aims to evaluate the anti-inflammatory, antinociceptive and antioxidant activities of new paratoluene sulphonamide derivatives. 


\section{Materials and Methods}

\section{Synthesis of the para-toluene sulphonamide derivatives}

The five sulphonamide derivatives \{2-[4-methylphenylsulphonamido] propanoic acid (b1), 2[4-methylphenylsulphonamido] acetic acid (b2), 2-[4-methylphenylsulphonamido]-4methylpentanoic acid (b3), 2-[4-methylphenylsulphonamido]-3-phenylpropanoic acid (b4), 2-[4methylphenylsulphonamido]-3-methylbutanoic acid (b5)\} were synthesized by the substitution of chlorine from p-toluenesulphonyl chloride under alkaline condition with alanine, glycine, leucine, phenylalanine and valine respectively, as described by Ikpa and Okoro [8].

\section{Experimental animals}

One hundred and five (105) Wistar albino rats of both sexes weighing 100-110 g, obtained from the laboratory Animal Unit of the Department of Veterinary, Physiology, Pharmacology, Biochemistry and Animal Health and Production, College of Veterinary Medicine, Michael Okpara University of Agriculture were used for the study. The animals were housed in aluminum cages at room temperature and under natural light/darkness cycles. They were supplied with clean drinking water and fed ad libitum with standard commercial pelleted feed (Vital feed ${ }^{\circledR}$ Nigeria). They were maintained in accordance with the recommendations of the Guide for the care and use of laboratory animals and the experimental protocol was approved by the institution's ethical committee [9].The rats were acclimatized for two weeks prior to the study. The experimental protocol was approved by the University Animal Ethics Committee with reference MOUAU/CVM/EAEC/2015/231.

\section{Acute oral toxicity}

The acute oral toxicity was assessed with "Up and Down" method as describe by Organization for Economic Cooperation and Development [10]. Twenty one rats were assigned to 7 groups of three rats. One group served as control (distilled water $10 \mathrm{ml} / \mathrm{kg}$ ) and other groups were dosed $2000 \mathrm{mg} / \mathrm{kg}$ of individual salts and were observed for 14 days for signs of toxicity and death.

\section{Egg albumin-induced paw edema in rat}

The modified rat paw edema method as described by Adzu et al [11] was used. Forty two rats of both sexes were used for the experiment. They were randomly divided into seven groups (A - G) of 6 rats each. Group A served as the control and received distilled water, $10 \mathrm{ml} / \mathrm{kg}$; group B served as positive control and received aspirin, $400 \mathrm{mg} / \mathrm{kg}$; and groups $\mathrm{C}-\mathrm{G}$ received samples $\mathrm{B}_{1}-\mathrm{B}_{5}$ respectively at the dose of $400 \mathrm{mg} / \mathrm{kg}$. All drugs were administered through oral route. One post treatment $0.1 \mathrm{ml}$ of fresh undiluted egg albumin was administered into the sub plantar space of the right hind limb. One hour post edema induction, the hind paw volumes of the rats were taken on the principle of volume displacement using digital weighing balance and water. The left paw volume of each rat was used as the control for each rat. The increase in paw volume of the right paw was calculated as follow: Increase in paw volume $=$ (paw volume of right hind limb - paw volume of the left hind limb).

\section{Tail flick method}

The modified rat paw edema method as described by Alam et al [12] was used. Forty two rats of both sexes were used for the experiment. They were randomly divided into seven groups (A - G) of 6 rats each. Group A served as the control and received distilled water, $10 \mathrm{ml} / \mathrm{kg}$; group B served as positive control and received aspirin, $400 \mathrm{mg} / \mathrm{kg}$; and groups $\mathrm{C}-\mathrm{G}$ received samples $\mathrm{B}_{1}-\mathrm{B}_{5}$ respectively at the dose of $400 \mathrm{mg} / \mathrm{kg}$. All drugs were administered through oral route. One post treatment $3 \mathrm{~cm}$ of the tip of the tail was immersed in warm water maintained at $55.0 \pm 1.0{ }^{\circ} \mathrm{C}$ in thermostatically regulated water bath. The tail withdrawal time (pain reaction time) was recorded for each rat with stopwatch.

\section{2, 2-Diphenyl-1-Picrylhydrazyl (DPPH) scavenging Assay}

The DPPH radical scavenging assay of the compounds were done as described by Ezeja et al. [13] at $25,50,100,200$ and $400 \mu \mathrm{g} / \mathrm{ml}$ in triplicate for each of the compounds. 


\section{Ferric Reducing Antioxidant Power}

The ferric reducing antioxidant power assay was done with method of Benzie and Strain, [14] as described in onoja et al [15]. The concentrations of 25, 50,100, 200 and $400 \mu \mathrm{g} / \mathrm{ml}$ was done in triplicate for each of the compound.

\section{Data analysis}

The results were presented as mean \pm standard error of mean (SEM). Data obtained were analyzed using one way analysis of variance (ANOVAs) and the variant means were separated by Least Significant Difference (LSD) of the different groups. Significance was accepted at the level of $\mathrm{p}<0.05$.

\section{Results}

\section{Acute toxicity}

The salts were tolerated by the rats as no signs of toxicity and death was observed throughout the 14 days of observation.

\section{Egg albumin-induced paw edema in rat}

The results are presented in Table 1 . The salts $(\mathrm{B} 1, \mathrm{~B} 2, \mathrm{~B} 3, \mathrm{~B} 4)$ significantly $(\mathrm{P}<0.05)$ reduced the paw edema in the treated rats when compared to the negative control group, while B5 did not produce significant $(\mathrm{P}>0.05)$ reduction in the paw edema of the treated rats when compared to negative control. The percentage edema inhibition of aspirin, B1, B2, B3, B4 and B5 $400 \mathrm{mg} / \mathrm{kg}$ are $38.65 \%, 41.18 \%, 54.63 \%, 42.02 \%, 29.41 \%$ and $14.29 \%$ respectively when compared to the negative control.

Table 1: Egg albumin-induced paw edema in rat

\begin{tabular}{|l|c|c|}
\hline TREATMENT & increase in paw volume (ml) & \% inhibition \\
\hline Distilled water $10 \mathrm{mg} / \mathrm{kg}$ & $1.19 \pm 0.07$ & - \\
\hline Aspirin $400 \mathrm{mg} / \mathrm{kg}$ & $0.73 \pm 0.03^{* * *}$ & 38.65 \\
\hline B1 $400 \mathrm{mg} / \mathrm{kg}$ & $0.70 \pm 0.03^{* * *}$ & 41.18 \\
\hline B2 $400 \mathrm{mg} / \mathrm{kg}$ & $0.54 \pm 0.18^{* * *}$ & 54.62 \\
\hline B3 $400 \mathrm{mg} / \mathrm{kg}$ & $0.69 \pm 0.05 * * *$ & 42.02 \\
\hline B $4400 \mathrm{mg} / \mathrm{kg}$ & $0.84 \pm 0.01 * *$ & 29.41 \\
\hline B5 $400 \mathrm{mg} / \mathrm{kg}$ & $1.02 \pm 0.09$ & 14.29 \\
\hline
\end{tabular}

${ }^{*} \mathrm{p}<0.05 ; * * \mathrm{p}<0.01 ; * * * \mathrm{p}<0.001$ when compared to negative control

\section{Tail flick test}

The results of the tail flick test are presented in Table 2. The aspirin, B1, B3, B4 and B5 400 $\mathrm{mg} / \mathrm{kg}$ produced a significant $(\mathrm{P}<0.05)$ increase in PRT in treated groups when compared to the negative control. The B2 reduced the PRT (no significance, $\mathrm{P}>0.05$ ) in treated group when compared to the negative control. The aspirin, B1, B2, B3, B4 and B5 $400 \mathrm{mg} / \mathrm{kg}$ caused $29.63 \%$, $25.51 \%,-8.23 \%, 18.51 \%, 72.02 \%$ and $29.63 \%$ increase in PRT respectively when compared to the negative control group.

Table 2: Tail flick method

\begin{tabular}{|l|l|l|}
\hline Treatment & Pain reaction time (Sec) & \% Inhibition \\
\hline Distilled water $10 \mathrm{mg} / \mathrm{kg}$ & $2.43 \pm 0.10$ & - \\
\hline Aspirin $400 \mathrm{mg} / \mathrm{kg}$ & $3.15 \pm 0.17^{* *}$ & 29.63 \\
\hline $\mathrm{B} 1400 \mathrm{mg} / \mathrm{kg}$ & $3.05 \pm 0.20^{* *}$ & 25.51 \\
\hline $\mathrm{B} 2400 \mathrm{mg} / \mathrm{kg}$ & $2.23 \pm 0.17$ & -8.23 \\
\hline B3 $400 \mathrm{mg} / \mathrm{kg}$ & $2.88 \pm 0.06$ & 18.51 \\
\hline B4 $400 \mathrm{mg} / \mathrm{kg}$ & $4.18 \pm 0.15^{* * *}$ & 72.02 \\
\hline B5 $400 \mathrm{mg} / \mathrm{kg}$ & $3.15 \pm 0.23^{* *}$ & 29.63 \\
\hline
\end{tabular}

$* \mathrm{p}<0.05 ; * * \mathrm{p}<0.01 ; * * * \mathrm{p}<0.001$ when compared to negative control 


\section{DPPH scavenging assay}

The result of the DPPH scavenging assay is presented in Table 3. The compounds did not produce antioxidant effects when compared to the ascorbic acid.

Table 3: DPPH scavenging assay

\begin{tabular}{|l|c|c|c|c|c|c|}
\hline \multicolumn{7}{|c|}{ Mean percentage antioxidant activity \pm SEM } \\
\hline $\begin{array}{l}\text { Concentration } \\
(\boldsymbol{\mu} \mathbf{g} / \mathbf{m L})\end{array}$ & $\mathbf{B 1}$ & $\mathbf{B 2}$ & $\mathbf{B 3}$ & $\mathbf{B 4}$ & $\mathbf{B 5}$ & $\begin{array}{c}\text { Ascorbic } \\
\text { acid }\end{array}$ \\
\hline 25 & $-1.76 \pm 0.90$ & $-0.87 \pm 1.08$ & $-0.48 \pm 1.11$ & $-0.80 \pm 0.64$ & $0.48 \pm 1.64$ & $94.59 \pm 0.57$ \\
\hline 50 & $0.32 \pm 0.50$ & $-1.74 \pm 1.10$ & $-0.73 \pm 0.10$ & $2.79 \pm 1.37$ & $-1.21 \pm 0.78$ & $96.46 \pm 0.04$ \\
\hline 100 & $-0.73 \pm 1.96$ & $0.69 \pm 0.74$ & $-1.37 \pm 0.62$ & $-0.05 \pm 1.62$ & $2.91 \pm 1.61$ & $96.22 \pm 0.18$ \\
\hline 200 & $-1.81 \pm 1.28$ & $1.15 \pm 1.52$ & $0.73 \pm 1.73$ & $-0.62 \pm 1.47$ & $-2.36 \pm 1.83$ & $96.31 \pm 0.09$ \\
\hline 400 & $1.44 \pm 1.01$ & $-0.09 \pm 0.73$ & $1.58 \pm 2.77$ & $-2.20 \pm 0.83$ & $-0.53 \pm 1.07$ & $96.16 \pm 0.19$ \\
\hline
\end{tabular}

\section{Ferric reducing antioxidant power assay}

The result of the FRAP assay is presented in Table 4. The sulphonamide derivatives did not produce a significant ferric reducing effect.

Table 4: Ferric reducing antioxidant power

\begin{tabular}{|l|l|l|l|l|c|}
\hline \multicolumn{7}{c}{ Mean FRAP value $(\boldsymbol{\mu M}) \pm$ SEM } \\
\hline $\begin{array}{c}\text { Concentration } \\
(\boldsymbol{\mu g} / \mathbf{m L})\end{array}$ & B1 & B2 & B3 & B4 & B5 \\
\hline 25 & $0.03 \pm 0.09$ & $-0.06 \pm 0.02$ & $0.12 \pm 0.33$ & $0.03 \pm 0.04$ & $-0.21 \pm 0.15$ \\
\hline 50 & $0.03 \pm 0.00$ & $-0.10 \pm 0.07$ & $-0.26 \pm 0.01$ & $0.05 \pm 0.10$ & $0.04 \pm 0.04$ \\
\hline 100 & $-0.13 \pm 0.10$ & $0.29 \pm 0.02$ & $-0.21 \pm 0.00$ & $0.42 \pm 0.04$ & $0.03 \pm 0.03$ \\
\hline 200 & $0.08 \pm 0.07$ & $-0.10 \pm 0.12$ & $-0.22 \pm 0.07$ & $0.12 \pm 0.07$ & $-0.01 \pm 0.05$ \\
\hline 400 & $-0.22 \pm 0.07$ & $0.00 \pm 0.01$ & $-0.05 \pm 0.01$ & $0.29 \pm 0.11$ & $-0.26 \pm 0.01$ \\
\hline
\end{tabular}

\section{Discussion}

The up and down method of acute oral toxicity test was adopted to reduced the number of animal required for the study. The result indicates that the sulphonamide derivatives were well tolerated by the treated rats and the LD50 was greater than $2000 \mathrm{mg} / \mathrm{kg}$ [10]. The sulphonamide derivatives did not elicit any antioxidant effect at the concentrations tested in both the DPPH and FRAP model. Thus, the sulphonamide derivatives have no antioxidant property.

Egg albumin is a standard phlogistic agent, which evokes inflammatory reaction by the release of inflammatory mediators like prostaglandins, histamine, serotonin, and attraction of neutrophils to the site of inflammation [16]. This may lead to increased vascular permeability resulting in edema and attributed to observed increase in paw size. Anti-inflammatory drugs like aspirin inhibit the production of prostaglandins and via inhibition of cyclooxygenase enzymes [17]. The anti-inflammatory and antinociceptive effects of the derivatives may be by the inhibition of cyclooxygenase activities, just as the aspirin [18]. Cyclooxygenase catalyse the biosynthesis of prostaglandins from arachidonic acid [15]. Again the mechanism of antinociceptive effects may be through the inhibition of pain perception, impulse transmission and/or elevation of pain threshold in the hypothalamus [19].

In conclusion, this study has demonstrated that the sulphonamide derivatives \{2-[4methylphenylsulphonamido] propanoic acid (b1), 2-[4-methylphenylsulphonamido] acetic acid (b2), 2-[4-methylphenylsulphonamido]-4-methylpentanoic acid (b3), 2-[4methylphenylsulphonamido]-3-phenylpropanoic acid (b4), 2-[4-methylphenylsulphonamido]-3methylbutanoic acid (b5)\} exhibited various anti-inflammatory and antinociceptive activities in the animal models. This however, may be due to the ability of the extract to suppress the release of endogenous inflammatory mediators. 


\section{References}

[1] R. Davicino et al., Different activities of Schinus areira L.: anti-inflammatory or proinflammatory effect, Immunopharmacol. Immunotoxicol. 32(4) (2010) 620-627.

[2] A.N, Shikov et al., Anti-inflammatory effect of Pinus sibirica oil extract in animal models, J. Nat. Med. 62 (2008) 436-440.

[3] S. Ahmad et al., Synthesis and biological evaluation of some novel 6-aryl-2-(p-sulfamylphenyl)4,5-dihydropyridazin-3(2H)-ones as anti-cancer, antimicrobial, and anti-inflammatory agents, J. Enzyme Inhib. Med. Chem. 25 (2010) 266-271.

[4] A.G. Habeeb, P.N. Praveen Rao, E.E. Knaus, Design and Synthesis of Celecoxib and Rofecoxib Analogues as Selective Cyclooxygenase-2 (COX-2) Inhibitors: Replacement of Sulfonamide and Methylsulfonyl Pharmacophores by an Azido Bioisostere, J. Med. Chem. 44 (2001) 3039-3042.

[5] A. Casini, A. Scozzafava, C.T. Supuran, Sulfonamide derivatives with protease inhibitory action as anticancer, anti-inflammatory and antiviral agents, Exp. Opin. Ther. Pat. 12 (2002) 1307-1327.

[6] A. Kołaczek et al., Biological activity and synthesis of sulfonamide derivatives: a brief review, Chemik. 68 (2014) 620-628

[7] N. Anand, Sulfonamides and Sulfons, In M.E. Wolff (Ed.), Burger's Medicinal Chemistry, Vol. 2, 5th ed, New York, Wiley- Interscience, 1996, Chapter 33.

[8] C.B.C. Ikpa, U.C. Okoro, Synthesis of new paratoluene sulphonamide derivatives of amino acids and their anti bacterial activities, IOSR Journal of Applied Chemistry. 9 (6) (Ver. II) (2016) 31-34.

[9] J.W. Ward, J.R. Elsea, Animal case and use in drug fate and metabolism, In: R.G. Edward, L.H. Jean, (Eds), Methods and Techniques, 1st edi. New York, Markel Dekker, 1997.

[10] Organization for Economic Cooperation and Development, OECD guidelines for the testing of chemicals, acute oral toxicity - up-and down procedure, No. 425. Paris, Organization for Economic Cooperation and Development, 2008. [Online] Available from: http://www.oecdilibrary.org/docserver/download/9742501 e.pdf? expires $=1437730561 \& \mathrm{id}=\mathrm{id} \&$ accname $=$ guest\&chec ksum=0B6C86B8F1B2E751997E5F54CFDF8F5E [Accessed on 5th May, 2015].

[11] B. Adzu et al., Anti-inflammatory and antinociceptive effects of Sphaeranthus senegalensis, J. Ethnopharmacol. 84 (2003) 169-173.

[12] M.A. Alam et al., Antinociceptive and anti-inflammatory properties of Ruellia tuberosa, Pharm. Biol. 47 (3) (2009) 209-214.

[13] M.I. Ezeja et al., Anti-inflammatory and Antioxidant Activities of the Methanolic Leaf Extract of Cissus aralioides, Am. J. Pharmacol. Sci. 3 (2015) 1-6.

[14] F.F. Benzie, J.J. Strain, Ferric reducing/Antioxidant power Assay: Direct measure of total antioxidant activity of biological fluids and modified version for simultaneous measurement of total antioxidant power and ascorbic acid concentration, Methods Enzymol. 299 (1999) 15-23.

[15] S.O. Onoja et al., Antioxidant, anti-inflammatory and antinociceptive activities of methanolic extract of Justicia secunda Vahl leaf, Alex. J. Med. (2016) in press. http://dx.doi.org/10.1016/j.ajme.2016.06.001.

[16] F.C Vilela et al., Anti-inflammatory and antipyretic effects of Sonchus oleraceus in rats, J. Ethnopharmacol. 127 (2010) 737-741.

[17] I.C. Obidike et al., The anti-inflammatory and antinociceptive properties of the chloroform fraction from Phyllanthus niruri plant is mediated via the peripheral nervous system, J. Diet. Suppl. 7 (4) (2010) 341-350.

[18] M.S. Brandão et al., Antinociceptive effect of lecythis pisonis camb. (lecythidaceae) in models of acute pain in mice, J. Ethnopharmacol. 146 (2013) 180-186.

[19] A.O.T. Ashafa et al., Evaluation of aqueous extract of Felicia muricata leaves for antiinflammatory, antinociceptive, and antipyretic activities, Pharm. Biol. 48(9) (2010) 994-1001. 